\title{
IMPLEMENTASI KEBIJAKAN E-GOVERNMENT PADA BADAN PERENCANAAN PEMBANGUNAN DAERAH KABUPATEN NGANJUK
}

\author{
E-Government Implementation in Regional Development Agency in Nganjuk Regency
}

\author{
Rubiyanto $^{1}$ \\ ${ }^{1}$ Magister Ilmu Administrasi Universitas Kadiri
}

\begin{abstract}
Abstrak
Implementasi Kebijakan E-Government Pada Badan Perencanaan Pembangunan Daerah Kabupaten Nganjuk. E-Government merupakan bentuk implementasi pelayanan publik yang berbasis teknologi informasi dan komunikasi yang bertujuan untuk membuat proses kerja dalam pemerintahan menjadi lebih sederhana, lebih akurat, responsive dan transparan. Dengan dikeluarkannya Instruksi Presiden Nomor 3 Tahun 2003, menghimbau kepada seluruh instansi pemerintah untuk menerapkan e-Government. BAPPEDA telah menerapkan e-Government melalui Sistem Informasi Perencanaan Pembangunan Daerah atau e-Planning. Penelitian ini bertujuan untuk memperoleh pemahaman tentang Implementasi Kebijakan eGovernment Pada Badan Perencanaan Pembangunan Daerah Kabupaten Nganjuk. Teknik analisis data menggunakan Teknik Analisis Data Kualitatif menurut Miles dan Huberman. Hasil penelitian menunjukkan bahwa Implementasi Kebijakan e-Government Pada Badan Perencanaan Pembangunan Daerah Kabupaten Nganjuk telah dilaksanakan sesuai dengan Instruksi Presiden Nomor 3 Tahun 2003, namun dalam pelaksanaannya terdapat beberapa kendala yang dapat memperlambat proses implementasi e-Government itu sendiri.
\end{abstract}

Kata Kunci: Implementasi; e-Government; e-Planning

\begin{abstract}
E-Government program is a form of the implementation of public services based information technology and communication that covertly designed to make the process of working in the government of into simpler ones, more accurate, responsive and transparent. With the establishment of presidential instruction no 3 2003, instructed that all government agencies apply for the e-Government program. BAPPEDA has implemented through a system of eGovernment program information regional development planning or e-Planning. This study determines to reveal an understanding of the e-Government of policy on Regional Development Planning Board District Nganjuk. Technique data analysis using a technique qualitative according to data analysis Miles and Huberman. The research results show that of policy e-Government on Regional Development Planning Board District Nganjuk has been implemented by an instruction of the president number three years 2003; however, in practice, there are several problems can slow process implementation e-Government itself.
\end{abstract}

Keywords: implementation; e-government; e-planning

\section{A. PENDAHULUAN}

E-Government merupakan bentuk implementasi pelayanan publik yang berbasis teknologi informasi dan komunikasi, sebagai media informasi dan komunikasi interaktif antara pemerintah dengan pihak-pihak lain baik kelompok masyarakat, kalangan bisnis maupun antar sesama lembaga pemerintahan. Tujuan eGovernment adalah untuk membuat proses kerja dalam pemerintahan menjadi lebih sederhana, lebih akurat, responsive dan membentuk pemerintahan yang transparan. Implementasi eGovernment dalam penerapannya dimulai dari bentuk layanan yang sederhana yaitu penyediaan informasi dan data-data berbasis komputer tentang pelaksanaan penyelenggaraan pemerintahan dan pembangunan sebagai bentuk wujud keterbukaan (transparancy) dalam pelaksanaan pelayanan publik.

Tahun 2003 menjadi tonggak baru dalam implementasi e-Government di Indonesia, yaitu dengan dikeluarkannya Instruksi Presiden Nomor 3 Tahun 2003 tentang Kebijakan dan Strategi Nasional Pengembangan e-Government. Semenjak Inpres tersebut di sahkan, perubahan demi perubahan mulai tercipta. Instansi 
pemerintah seakan berlomba-lomba menciptakan pelayanan publik yang efektif dan efisien. Tercatat, beberapa instansi pemerintah dari level Departemen hingga Kabupaten/Kota, mulai menggunakan teknologi informasi sebagai alat yang memudahkan mereka dalam bekerja sesuai kebutuhan dan tujuan pembangunan yang telah mereka rencanakan.

Selanjutnya, dengan berlakunya UndangUndang Nomor 23 tahun 2014 tentang Pemerintah Daerah, penyelenggaraan otonomi daerah dilaksanakan dengan memberikan kewenangan yang luas, nyata dan bertanggung jawab kepada daerah. Agar pelaksanaan pemerintahan dan pembangunan tersebut benarbenar memiliki manfaat dan dampak jangka panjang bagi masyarakat luas, pelaksanaan pemerintahan dan pembangunan itu sendiri memerlukan suatu upaya keberlanjutan dan kesinambungan.

Pentingnya e-Government pada pemerintah daerah dalam mewujudkan pemerintahan yang baik dan Badan Perencanaan Pembangunan Daerah (BAPPEDA) sebagai salah satu Organisasi Perangkat Daerah yang telah mengembangkan aplikasi e-Planning dalam kerangka implementasi e-Government tersebut benar-benar sangat membantu dalam menunjang tugas pokok dan fungsinya serta sasaran yang ingin dicapai yaitu tercapainya efisiensi dan efektifitas sistem serta proses perencanaan pembangunan daerah melalui ketersediaan pemutkahiran dan tingkat aksesibilitas data yang akuntabel terhadap berbagai produk perencanaan. Oleh karena itu penulis menganggap perlu dilakukan suatu penelitian tentang e-Government di suatu Organisasi Perangkat Daerah yang dituangkan ke dalam tesis dengan judul "Implementasi e-Government pada Badan Perencanaan Pembangunan Daerah Kabupaten Nganjuk".

Berdasarkan uraian diatas maka yang menjadi fokus dalam penelitian ini adalah :

1. Pemahaman Aparatur Sipil Negara tentang e-Government.

2. Kebijakan pemerintah daerah yang mendukung implementasi e-Government di Badan Perencanaan Pembangunan Daerah Kabupaten Nganjuk.

3. Sumber daya finansial pendukung terwujudnya e-Government di Badan Perencanaan Pembangunan Daerah Kabupaten Nganjuk.

4. Infrastruktur pendukung implementasi eGovernment di Badan Perencanaan Pembangunan Daerah Kabupaten Nganjuk.
5. Sumber Daya Aparatur pendukung tercapainya e-Government di Badan Perencanaan Pembangunan Daerah Kabupaten Nganjuk.

6. Proses perencanaan pembangunan setelah adanya e-Planning.

7. Publikasi Sistem Informasi Perencanaan Pembangunan Daerah (e-Planning) kepada Organisasi Perangkat Daerah Kabupaten Nganjuk.

8. Nilai / Manfaat yang diperoleh dengan adanya implementasi e-Government melalui ePlanning bagi Badan Perencanaan Pembangunan Daerah maupun Organisasi Perangkat Daerah Kabupaten Nganjuk.

Berdasarkan latar belakang permasalahan yang telah dikemukakan secara singkat diatas dan untuk memberi arah dalam pelaksanaan penelitian, maka perumusan masalah yang dikemukakan adalah sebagai berikut :

1. Bagaimanakah Implementasi eGovernment pada Badan Perencanaan Pembangunan Daerah Kabupaten Nganjuk?

2. Hambatan-hambatan apa saja yang dihadapi Badan Perencanaan Pembangunan Daerah Kabupaten Nganjuk dalam Implementasi e-Government?

Tujuan yang hendak dicapai melalui penelitian ini adalah :

1. Untuk memperoleh pemahaman tentang Implementasi e-Government pada Badan Perencanaan Pembangunan Daerah Kabupaten Nganjuk.

2. Untuk memperoleh pemahaman tentang hambatan-hambatan yang dihadapi dalam Implementasi e-Government pada Badan Perencanaan Pembangunan Daerah Kabupaten Nganjuk.

\section{B. KERANGKA TEORI Kebijakan Publik}

Istilah kebijakan publik lebih sering dipergunakan dalam kaitannya dengan tindakantindakan atau kegiatan pemerintah, hal tersebut sebagaimana dikemukakan oleh Carl J. Friedrick dalam Solichin (2004:3) yang menyatakan bahwa kebijakan ialah: "Suatu tindakan yang mengarah pada tujuan yang diusulkan oleh seseorang, kelompok atau pemerintah dalam lingkungan tertentu sehubungan dengan adanya hambatanhambatan tertentu seraya mencari peluangpeluang untuk mencapai tujuan atau mewujudkan sasaran yang diinginkan." Pengertian kebijakan yang disebutkan di atas sebagai suatu tindakan yang diusulkan oleh pemerintah, lain halnya pendapat George C. Edwads III dan Ira Sharkansky dalam Islamy ( 2001:18-19) yang menyatakan bahwa "Kebijakan Negara adalah suatu tindakan yang dilakukan 
atau tidak dilakukan pemerintah", sehingga suatu kebijakan tidak hanya suatu tindakan yang diusulkan tetapi juga yang tidak dilaksanakan, demikian pula pendapat Thomas Dye dalam Subarsono (2005:2) yang mengatakan kebijakan publik adalah apapun pilihan pemerintah untuk melakukan atau tidak melakukan, definisi tersebut mengandung makna bahwa (1) kebijakan publik tersebut dibuat oleh badan pemerintah, bukan organisasi swasta; (2) kebijakan publik menyangkut pilihan yang harus dilakukan atau tidak dilakukan oleh pemerintah.

Dengan pengertian-pengertian kebijakan publik di atas disimpulkan bahwa kebijakan adalah serangkaian tindakan pemerintah yang bersifat mengatur dalam rangka merespon permasalahan yang dihadapi masyarakat dan mempunyai tujuan tertentu, berorientasi kepada kepentingan publik (masyarakat) dan bertujuan untuk mengatasi masalah, memenuhi keinginan dan tuntutan seluruh anggota masyarakat. Kebijakan juga memuat semua tindakan pemerintah baik yang dilakukan maupun tidak dilakukan oleh pemerintah yang dalam pelaksanaanya terdapat unsur pemaksaan kepada pelaksana atau pengguna kebijakan agar dipatuhi, hal ini sejalan dengan pendapat Easton (Islamy, 2001:19) bahwa kebijakan mengandung nilai paksaan yang secara sah dapat dilakukan pemerintah sebagai pembuat kebijakan.

\section{Implementasi Kebijakan Publik}

Implementasi kebijakan merupakan suatu analisis dengan lebih melakukan retropeksi dari pada prospeksi dengan tujuan ganda, yaitu : pertama memberi informasi bagaimana programprogram tersebut dapat terlaksana, kedua menunjukkan faktor-faktor yang dapat diubah agar diperoleh capaian hasil yang lebih baik yang dapat memberikan perubahan implementasi atau program baru. Sebagaimana Budi Winarno (1998:72) menyatakan proses implementasi memiliki variabel atau faktor yang membentuk kaitan ( linkage ) antara kebijakan dan capaian ( performance ). Variabel tersebut merupakan variabel bebas dan variabel terikat yang saling berhubungan satu sama lainnya. Sebagaimana dikatakan di atas bahwa capaian kebijakan dipengaruhi adanya beberapa variabel, variabelvariabel tersebut ditunjukkan pada beberapa model Implementasi kebijakan, menurut Van Meter dan Van Horn (Samudra Wibawa,1994:19) Implementasi kebijakan dipengaruhi adanya komunikasi, sumber-sumber (sumber daya), kecenderungan/sikap dan struktur birokrasi, standard dan sasaran kebijakan serta kondisi sosial ekonomi dan politik. Spesifik Van Meter dan Van Horn lebih menekankan kepada kinerja kebijakan.

Selanjutnya Van Meter dan Van Horn (Solichin 2004:81) dalam model implementasi kebijakannya juga menganggap faktor komunikasi akan berpengaruh yaitu komunikasi antar organisasi terkait serta kegiatan-kegiatan pelaksanaannya mencakup antar hubungan dalam lingkungan sistem politik dengan kelompok-kelompok sasaran. Van Meter mengharapkan semua pelaksana harus memahami apa yang diidealkan oleh kebijakan yang implementasinya menjadi tanggung jawab mereka, organisasi atasan mestinya mampu mengkondisikan organisasi bawahan atau pelaksana, karena dalam implementasi sebuah program perlu dukungan dan koordinasi dengan instansi lain, untuk itu diperlukan koordinasi dan kerjasama bagi keberhasilan suatu program.

Menurut Van Meter dan Van Horn, implementasi yang berhasil merupakan fungsi dari kemampuan organisasi pelaksana Untuk melakukan apa yang diharapkan untuk dikerjakan. Van Meter dan Van Horn juga megemukakan bahwa kapasitas sebagai faktor yang berpengaruh bagi implementasi kebijakan (Budi Winarno, 2002 : 122).

\section{E-Government}

E-Government adalah pemanfaatan teknologi informasi dan komunikasi guna pelaksanaan pemerintahan yang efisien dan murah, meningkatkan pelayanan masyarakat dengan cara menyediakan sarana publik sehingga masyarakat mudah mendapatkan informasi (Caldow, disitasi Indrajit, 2006). Pendapat lain mengatakan bahwa e-Government adalah penggunaan teknologi informasi oleh pemerintah (seperti : Wide Area Network, Internet dan mobile computing) yang memungkinkan pemerintah untuk mentransformasikan hubungan dengan masyarakat, dunia bisnis dan pihak yang berkepentingan. Dalam prakteknya, eGovernment adalah penggunaan internet untuk melakukan urusan pemerintah dan penyediaan pelayanan publik yang lebih baik yang berorientasi pada pelayanan masyarakat (http://www.worldbank.org, disitasi Indrajit, 2006).

Beberapa definisi lain mengenai eGovernment menurut beberapa sumber sebagai berikut :

1) Deloitte Research (2000) : menggunakan teknologi untuk pelayanan masyarakat, bisnis dan pegawai yang lebih baik.

2) West (2001, p.863) : pengiriman informasi kepemerintahan dan layanan online melalui internet atau perlengkapan digital lainnya. 
3) Cook et.al (2002) : e-Government memiliki empat dimensi dalam hubungannya dengan fungsi dan kegiatan kepemerintahan: eservices (mengirim informasi secara elektronik/online), management (menggunakan TIK untuk meningkatkan manajemen dan komunikasi di internal atau di luar struktur kepemerintahan), e-democracy (menggunakan TIK untuk mendapatkan partisipasi masyarakat dalam kegiatan demikrasi), dan e-commerce (transaksi online dari kebutuhan dan layanan).

4) Bhatnagar (2002): membagi dan melayani masyarakat dan bisnis dengan tujuan mengurangi korupsi, mengurangi waktu dan biaya, dan meningkatkan transparansi.

5) World Bank (2002): mengguanakan TIK untuk mengubah dan meningkatkan hubungan antar pemerintah, masyarakatbisnis dan unit kepemerintahan lainnya.

6) Mark Forman (2005): penerapan TIK untuk meningkatkan kinerja dari fungsi dan layanan pemerintah tradisional.

7) World Bank Group (2006): penggunaan TI oleh badan-badan pemerintah, seperti: wide area network, internet dan mobile computing yang mempunyai kemampuan untuk mengubah hubungan dengan warga negara, pelaku bisnis dan badan pemerintah lainnya.

8) Legislative Analyst's office (2006): sebuah proses transaksi bisnis antara masyarakat dan pemerintah melalui penggunaan sistem yang terotomasi dan jaringan internet, biasanya disebut world wide web.

Sehingga dapat disimpulkan bahwa pengembangan e-Government merupakan upaya untuk mengembangkan penyelenggaraan kepemerintahan yang berbasis elektronik dalam rangka meningkatkan kualitas layanan publik secara efektif dan efisien. Menurut Dr. Nag Yeon Lee terdapat 8 (delapan) model e-Government, yaitu:

1) Pemerintah ke masyarakat (G2C): penyampaian layanan publik dan informasi satu arah oleh pemerintah ke masyarakat.

2) Masyarakat ke pemerintah (C2G): memungkinkan pertukaran informasi dan komunikasi antara masyarakat dan pemerintah.

3) Pemerintah ke bisnis (G2B): transaksitransaksi elektronik dimana pemerintah menyediakan berbagai informasi yang dibutuhkan bagi kalangan bisnis untuk bertransaksi dengan pemerintah. Sebagai contoh yaitu sistem e-procurement.

4) Bisnis ke pemerintah (B2G): mengarah kepada pemasaran produk dan jasa ke pemerintah untuk membantu pemerintah menjadi lebih efisien, terjadi peningkatan proses bisnis dan manajemen data ektronik. Sistem e- procurement adalah contoh aplikasi yang memfasilitasi baik interaksi G2B maupun B2G.

5) Pemrintah ke pegawai (G2E): terdiri dari inisiatif-inisiatif yang memfasilitasi manajemen pelayanan dan komunikasi internal dengan pegawai pemrintahan.

6) Pemerintah ke pemerintah (G2G): memungkinkan komunikasi dan pertukaran informasi online antar departemen atau lembaga pemerintahan melalui basis data terintegrasi sehingga berdampak pada efisiensi dan efektivitas.

7) Pemerintah ke ke organisasi nirlaba (G2N): pemerintah menydiakan informasi bagi organisasi nirlaba, partai politik, atau orrganisasi sosial.

8) Organisasi nirlaba ke pemerinta (N2G): memungkinakan pertukaran informasi dan komunikasi antara pemerintah dan organisasi nirlaba, partai politik dan organisasi sosial.

Menurut Lee (2009) tujuan dari eGovernment adalah penyampaian layanan pemerintah kepada masyarakat dengan lebih efektif. Umumnya semakin banyak layanan online yang tersedia dan semakin luas penggunaan layanan tersebut, maka akan semakin besar dampaknya terhadap eGovernment. Kemudian menurut Raharjo (2001) manfaat dari penerapan e-Government adalah :

1) Palayanan servis yang labih baik kepda masyarakat. Informasi dapat disediakan 24 jam sehari, 7 hari seminggu, tanpa harus menunggu dibukanya kantor. Informasi dapat dicari dari kantor, rumah tanpa harus secara fisik datang ke kantor pemerintah.

2) Peningkatan hubungan antara pemrintah, pelaku bisnis dan masyarakat umum. Adanya keterbukaan (transparansi) maka diharapkan hubungan antara berbagai pihak menjadi lebih baik. Keterbukaan ini menghilangkan saling curiga dan kekesalan dari semua pihak.

3) Pemberdayaan masyarakat melalui informasi yang mudah diperoleh. Dengan adanya informasi yang mencukupi, masyarakat akan belajar untuk menentukan pilihannya.

4) Pelaksanaan pemerintahan yang lebih efisien. Sebagai contoh koordinasi pemerintah dapar dilakukan melalui email atau bahkan video conferencing. Bagi Indonesia yang sangat luas areanya sangat besar, hal ini sangat membantu.

Menurut Inpres No. 3 Tahun 2003, pengembangan e-Government merupakan upaya untuk mengembangkan penyelenggaraan kepemerintahan yang berbasis (menggunakan) elektronik dalam rangka meningkatkan kualitas layanan publik secara efekti dan efisien. Melalui pengembangan e-Government dilakukan penataan sistem manajemen dan proses kerja di 
lingkungan pemerintah dengan mengoptimalkan pemanfaatan teknologi informasi. Pemanfaatan teknologi informasi tersebut mencakup 2 (dua) aktivitas yang berkaitan, yaitu (1) pengolahan data, pengelolaan informasi, sistem manajemen dan proses kerja secara elektronis; pemanfaatan kemajuan teknologi informasi agar pelayanan publik dapat diakses secara mudah dan murah oleh masyarakat di seluruh wilayah negara.

\section{METODE PENELITIAN}

Perspektif atau paradigma penelitian yang peneliti gunakan adalah kualitatif yang memiliki tahapan berfikir kritis-ilmiah, yang mana seorang peneliti memulai berfikir secara induktif, yaitu menangkap berbagai fakta atau fenomena-fenomena sosial, melalui pengamatan di lapangan, kemudian menganalisisnya dan kemudian berupaya melakukan teorisasi berdasarkan apa yang diamati itu (Bungin, 2010: 6). Penelitian kualitatif merupakan proses penelitian yang menghasilkan data deskripsi berupa kata-kata tertulis atau lisan dari orangorang dan pelaku yang dapat diamati sehingga penulis bisa mendapatkan data yang objektif dalam rangka mengetahui dan memahami bagaimana implementasi e-Government pada Badan Perencanaan Pembangunan Daerah Kabupaten Nganjuk.

Lokasi penelitian merupakan tempat dimana penelitian dilakukan untuk memperoleh data dan informasi yang berkaitan dengan permasalahan yang diangkat oleh peneliti. Dalam penelitian ini, yang menjadi lokasi penelitian adalah Badan Perencanaan Pembangunan Daerah Kabupaten Nganjuk.

Subyek penelitian adalah subyek yang dituju untuk diteliti oleh peneliti. Penentuan sumber data dalam penelitian ini dilakukan secara purposive sampling, yaitu pemilihan sumber data berdasarkan pertimbangan tertentu, karena peneliti menganggap bahwa informan tersebut dapat lebih dipercaya untuk menjadi sumber data. Berdasarkan kriteria sumber data atau informan diatas maka peneliti memilih sumber data atau informan yang bekerja di lokasi penelitian yaitu Badan Perencanaan Pembangunan Daerah Kabupaten Nganjuk, karena sumber data atau informan tersebut dianggap paling tahu tentang informasi yang dibutuhkan dalam penelitian, sehingga akan memudahkan peneliti dalam menelusuri siatuasi yang diteliti.

Dalam penelitian ini, teknik pengumpulan data dilakukan dengan cara Pengamatan (observasi), Wawancara (interview), dan Dokumentasi Analisa data analisis menggunakan model interaktif menurut Miles dan Huberman (2014) terdiri dari tiga sub proses yang saling berkaitan yaitu setelah Pengumpulan Data yaitu: Data Condensation atau Kondensasi Data (reduksi data), Data Display atau Penyajian Data, dan Conclusion/Verifying atau Penarikan Kesimpulan/Verifikasi.

\section{PEMBAHASAN \\ Implementasi Kebijakan E-Government di Badan Perencanaan Pembangunan Daerah Kabupaten Nganjuk.}

Implementasi kebijakan e-Government di Badan Perencanaan Pembangunan Daerah Kabupaten Nganjuk sudah terealisasi dengan diterapkannya sistem aplikasi e-Planning dalam menunjang tugas pokok dan fungsinya di bidang perencanaan pembangunan daerah. E-Planning memanfaatkan teknologi informasi dan komunikasi untuk pengolahan data dan bersifat rutin. Melalui e-Planning, sistem perencanaan pembangunan daerah di Kabupaten Nganjuk menjadi lebih tertib, transparan dan hemat biaya. Untuk mengetahui sejauh mana implementasi eGovernment di Badan Perencanaan Pembangunan Daerah Kabupaten Nganjuk, kita akan membahas satu per satu dari hasil penelitian, yaitu sebagai berikut :

\section{Pemahaman Aparatur Sipil Negara tentang e-Government.}

Berdasarkan hasil wawancara dari beberapa narasumber diketahui bahwa masih rendahnya pemahaman Aparatur Sipil Negara di lingkungan pemerintah daerah Kabupaten Nganjuk tentang konsep e-Government. Rendahnya pemahaman Aparatur Sipil Negara tentang konsep eGoverment menjadi salah satu kendala dalam upaya penerapan e-Government di Organisasi Perangkat Daerah. Pemahaman Aparatur Sipil Negara di Kabupaten Nganjuk tentang eGovernment masih kurang, terlihat dengan banyaknya Organisasi Perangkat Daerah yang belum bisa menerapkan konsep e-Government di instansinya. Dalam penerapan e-Government sebelum ke pembentukan sistem aplikasinya, para Aparatur Sipil Negara seharusnya mengetahui dan memahami apa itu konsep e-Government. Untuk mengetahui konsep e-Government tersebut para Aparatur Sipil Negara dapat melakukan studi tentang konsep e-Government baik secara mandiri maupun mengikuti seminar-seminar tentang e-Government. Dengan begitu untuk kedepannya akan lebih mudah dalam implementasi kebijakan e-Government di Organisasi Perangkat Daerah khususnya di Kabupaten Nganjuk. 
2. Kebijakan Pemerintah Daerah Kabupaten Nganjuk tentang e-Government.

Unsur utama dan paling krusial yang harus dimiliki di dalam implementasi eGovernment di suatu daerah adalah adanya dukungan dari pemerintah daerah salah satunya yaitu berupa kebijakan dan peraturan daerah tentang pelaksanaan e-Government. Tanpa adanya dukungan pemerintah dari segi hukum, berbagai inisiatif pembangunan dan pengembangan e-Government tidak akan berjalan dengan baik. Implementasi kebijakan eGovernment di Badan Perencanaan Pembangunan Daerah Kabupaten Nganjuk melalui Sistem Informasi Perencanaan Daerah (ePlanning) masih menggunakan peraturan perundang-undangan dari pemerintah pusat sebagai dasar penerapan dan yang melandasi pelaksanaannya, yaitu sebagai berikut :

1) Undang-undang Nomor 11 Tahun 2008 tentang Informasi dan Transaksi Elektronik.

2) Undang-undang Nomor 14 Tahun 2008 tentang Keterbukaan Informasi Publik.

3) Instruksi Presiden Republik Indonesia Nomor 3 Tahun 2003 tentang Kebijakan dan Strategi Nasional Pengembangan e-Government.

4) Undang-Undang Nomor 25 Tahun 2004 tentang Sistem Perencanaan Pembangunan Nasional.

5) Surat Ditjen Bina Bangda Nomor 40/5327/Bangda Tanggal 17 November 2016 tentang Penerapan Aplikasi e-Planning dalam Perencanaan Pembangunan Daerah.

3. Sumber Daya Finansial pendukung terwujudnya e-Planning di Badan Perencanaan Pembangunan Daerah Kabupaten Nganjuk.

Ketersediaan Sumber Daya Finansial menjadi salah satu unsur penting terwujudnya implementasi e-Government. Selama ini sistem teknologi informasi selalu dikenal sebagai sebuah aktifitas yang menggunakan teknologi canggih, membutuhkan biaya yang besar dan sangat susah diimplementasikan secara cepat dan tepat. Pemanfaatan teknologi ini tentunya tidak perlu sekaligus, harus selalu disesuaikan dengan perkembangan yang ada di daerah implementasiannya, tetapi dengan dasar yang kokoh, pembangunan teknologi ini dapat dilaksanakan secara berkesinambungan sehingga akhirnya akan membawa efisiensi dan efektifitas dalam sistem pelaksanaannya sesuai dengan tujuan dari pengimplementasian teknologi informasi yaitu mewujudkan sebuah sistem kerja yang efisien, efektif dan terintegrasi.

Dalam implementasi e-Government melalui sistem aplikasi e-Planning di Badan Perencanaan Pembangunan Daerah, semua pebiayaan berasal dari dana Anggaran Pendapatan Belanja Daerah (APBD). Untuk pembiayaannya dibedakan menjadi 3 (tiga), yaitu:

1) Pembiayaan untuk pengembangan aplikasi sistem e-Planning.

2) Pembiayaan untuk infrastruktur server ePlanning.

3) Pembiayaan untuk pengembangan Sumber Daya Aparatur.

Sumber daya finansial merupakan salah satu element penting dalam menunjang implementasi kebijakan e-Government karena setiap kegiatan pasti membutuhakn dana dan anggaran. Besarnya dana yang dibutuhkan untuk penerapan e-Governmen, maka komitmen dari pemerintah di dalam menyediakan dana dan anggaran sangat dibutuhkan.

4. Infrastruktur pendukung penerapan eGovernment di Badan Perencanaan Pembangunan Daerah Kabupaten Nganjuk.

Dukungan infrastruktur dalam implementasi kebijakan e-Government di Badan Perencanaan Pembangunan Daerah Kabupaten Nganjuk melalui sistem aplikasi e-Planning dapat diuraikan sebagai berikut, yaitu :

\section{a. Server}

Server merupakan komputer yang digunakan untuk memberikan layanan tertentu pada para pengguna komputer yang terhubung ke server tersebut.

b. Ruangan server

Ruangan server merupakan sebuah ruangan yang digunakan untuk menyimpan server (aplikasi dan database), perangkat jaringan (router, hub, dll) dan perangkat lainnya yang terkait dengan operasional sistem sehari-hari seperti UPS, AC, dan lain-lain. Ruangan server harus memiliki standar keamanan yang melindungi kerja perangkat-perangkat didalamnya, mulai suhu udara, kelembaban, kebakaran dan akses masuk dari orang-orang yang tidak berkepentingan.

c. Koneksi internet berlangganan. 
Koneksi internet merupakan salah satu upaya untuk penerapan aplikasi e-Government. Di Badan Perencanaan Pembangunan Daerah, untuk penyediaan koneksi internet melakukan kerjasama dengan pihak swasta.

5. Sumber Daya Aparatur pendukung tercapainya e-Government di Badan Perencanaan Pembangunan Daerah Kabupaten Nganjuk.

Sumber daya aparatur menjadi salah satu faktor pendukung tercapainya e-Government. Ketersediaan sumber daya aparatur yang memiliki kompetensi dan keahlian bidang teknologi informasi yang dibutuhkan dalam penerapan e-Government. Dengan modal sumber daya aparatur yang dimilki tersebut, Badan Perencanaan Pembangunan Daerah Kabupaten Nganjuk merasa cukup mampu untuk mengimplementasikan e-Government di instansinya.

Pengoperasian sistem aplikasi e-Planning tidak harus dibutuhkan sumber daya aparatur atau pegawai dengan kualifikasi bidang teknologi informasi melainkan bisa dari berbagai disiplin ilmu dengan syarat sudah pernah mengikuti pelatihan tentang e-Planning di Badan Perencanaan Pembangunan Daerah Kabupaten Nganjuk. Sumber daya aparatur yang bertugas mengoperasikan aplikasi e-Planning terdiri dari :

\section{Koordinator}

Koordinator disini adalah aparatur BAPPEDA Kabupaten Nganjuk yang menangani langsung ePlanning. Koordinator tersebut mempunyai tugas mengkoordinasikan penyusunan dokumen perencanaan dengan menggunakan alat bantu ePlanning;

\section{Narasumber}

Narasumber dibutuhkan sebagai tenaga pendamping dalam implementasi sistem aplikasi e-Planning. Narasumber berasal dari konsultan atau pihak swasta yang menyediakan sistem aplikasi e-Planning dan aparatur BAPPEDA Kabupaten Nganjuk yang menangani langsung sistem aplikasi e-Planning. Admin

Admin merupakan aparatur BAPPEDA Kabupaten Nganjuk yang diberi tugas mengatur aksesibilitas pengguna aplikasi e-Planning.

\section{Operator}

Operator dibagi menjadi 2, yaitu : operator di BAPPEDA Kabupaten Nganjuk dan operator Organisasi Perangkat Daerah.
6. Proses penyusunan perencanaan pembangunan berbasis e-Planning.

Perencanaan Pembangunan Daerah Kabupaten Nganjuk merupakan bagian dari Perencanaan Pembangunan Nasional, sehingga dalam penyusunannya harus mengacu pada Perencanaan Pembangunan Nasional.

Undang-Undang Nomor 25 Tahun 2004 tentang Sistem Perencanaan Pembangunan Nasional merupakan dasar penyusunan perencanaan pembangunan daerah Kabupaten Nganjuk dapat dituangkan dalam modul aplikasi Sistem Informasi Perencanaan Daerah Kabupaten Nganjuk (e-Planning), yaitu sebagai berikut :
a. Pemasukan data Renstra
b. Pemasukan data Renja
c. Pemasukan data RPJMD
d. Pemasukan data RKPD
e. Penerbitan KUA-PPAS

Untuk entry data ke dalam sistem aplikasi ePlanning, untuk admin dibagi menjadi beberapa level admin, yaitu :

\section{a. User Level : ADMIN}

Tugas Admin antara lain:

1) Menyiapkan User Account dan Password bagi pengguna aplikasi

2) Menentukan jadwal input data

3) Menyiapkan referensi

4) Memberikan pengumuman dan merespon tanya jawab

\section{b. User Level: OPERATOR}

Tugas Operator antara lain :

1) Input referensi RPJMD (Prioritas, Sasaran, Indikator sasaran dan Program).

2) Input referensi Renstra.

3) Input referensi Urusan Pemerintahan.

4) Input rencana pendapatan dan belanja daerah.

5) Mengisi Pagu Sementara masing-masing OPD.

6) Migrasi database dari RKPD ke KUAPPAS 
7) Menyiapkan laporan dan eksekutif (bila diperlukan)

8) Memberikan pengumuman dan merespon tanya jawab.

d. User Level: Organisasi Perangkat Daerah

Tugasnya, antara lain :

- $\quad$ Input data kegiatan

Proses perencanaan melalui sistem aplikasi ePlanning tersebut meliputi beberapa tahapan, yaitu :

1. input yang meliputi informasi program, kegiatan dan anggaran yang dimiliki oleh Organisasi Perangkat daerah sesuai dengan visi dan misi;

2. proses yang memuat informasi mengenai waktu pelaksanaan program dan kegiatan Organisasi Perangkat Daerah;

3. output yang memuat informasi mengenai hasil yang diperoleh dari pelaksanaan program dan kegiatan Organisasi Perangkat Daerah;

4. outcome yang memberikan informasi mengenai dampak yang akan diperoleh apabila program dan kegiatan yang direncanakan telah terlaksana.

7. Publikasi penggunaan e-Planning kepada Organisasi Perangkat Daerah di Kabupaten Nganjuk.

Publikasi merupakan upaya untuk pemberitahuan dan memperkenalkan suatu hal kepada sasaran. Dalam hal ini publikasi penggunaan sistem aplikasi e-Planning kepada Organisasi Perangkat Daerah di lingkungan Pemerintah Daerah Kabupaten Nganjuk. Publikasi tersebut dapat diuraikan sebagai berikut

1. Sosialisasi

2. Pelatihan

3. Surat dinas

Pada waktu publikasi melalui sosialisasi maupun pada waktu pelatihan penggunaan e-Planning juga disampaikan adanya batasan waktu input kegiatan, dan perubahan kegiatan sesuai dengan peraturan yang telah ditetapkan. Publikasi dimaksudkan agar penggunaan e-Planning bisa lebih tertib.

8. Nilai / Manfaat e-Planning bagi Badan Perencanaan Pembangunan Daerah Kabupaten
Nganjuk maupun Organisasi Perangkat Daerah di Kabupaten Nganjuk.

Kunci kesuksesan penerapan e-Government salah satunya adalah adanya nilai atau manfaat. Berbagai kebijakan tidak akan diterapkan jika tidak mempunyai unsur nilai atau manfaat di dalamnya. Kebijakan penerapan e-Government mempunyai berbagai manfaat. Sedangakan ePlanning sendiri yang merupakan bagian dari eGovernment juga mempunyai nilai/manfaat. Adapun manfaat yang peroleh dengan ditetapkannya e-Planning adalah sebagai berikut :

a. Manfaat e-Planning bagi Badan Perencanaan Pembangunan Daerah Kabupaten Nganjuk :

1. Proses lebih mudah dan cepat.

2. Akan lebih fokus mengarah pada target sasaran pembangunan sesuai prioritas pembangunan dalam Rencana Pembangunan Jangka Menengah Daerah (RPJMD).

3. Meminimalisisr terjadinya kesalahan entry data.

b. Nilai / Manfaat e-Planning Bagi Organisasi Perangkat Daerah

1. Mempermudah proses pengajuan usulan program dan kegiatan.

2. Proses penyusunan Kebijakan Umum Anggaran dan Prioritas Plafon Anggaran Sementara (KUA-PPAS) sesuai prosedur.

3. Proses pengambilan kebijakan yang transparan.

\section{Hambatan-hamabatan dalam Implementasi e- Government di Badan Perencanaan Pembangunan Daerah Kabupaten Nganjuk}

1. Belum adanya Kebijakan Pemerintah Daerah yang mendukung implementasi eGovernment di Daerah.

Dari hasil penelitian di lapangan, ditemukan bahwa dalam pelaksanaan implementasi eGovernment di lingkungan pemerintah daerah Kabupaten Nganjuk masih menggunakan peraturan-peraturan pemerintah pusat sebagai dasar pelaksanaan, yaitu :

a. Undang-Undang Nomor 11 tahun 2008 tentang Informasi dan Transaksi Elektronik.

b. Undang-Undang Nomor 14 tahun 2008 tentang Keterbukaan Informasi Publik. 
c. Instruksi Presiden RI Nomor 3 Tahun 2003 tentang kebijakan dan strategi nasional pengembangan e-Government.

Dalam Inpres Nomor 3 Tahun 2003 tersebut menginstruksikan kepada Menteri, Kepala Lembaga Tertinggi dan Tinggi Negara, Panglima Tentara Nasional Indonesia, Kepala Kepolisian Negara Republik Indonesia, Jaksa Agung Republik Indonesia, Gubernur, dan Bupati/Walikota untuk mengambil langkahlangkah yang diperlukan sesuai tugas, fungsi dan kewenangannya masing-masing guna terlaksananya pengembangan e-Government secara nasional dengan berpedoman pada Kebijakan dan Strategi Nasional Pengembangan e-Government.

2. Keterbatasan sumber daya finansial dalam mendukung implementasi e-Government di Badan Perencanaan Pembangunan Daerah Kabupaten Nganjuk.

Dana dan anggaran merupakan salah satu faktor yang paling krusial dalam upaya pelaksanaan implementasi e-Government di daerah. Sistem aplikasi yang melibatkan banyak pihak tentunya membutuhkan dana yang besar. Dana dan anggaran yang besar tersebut bisa menjadi penghambat dalam implementasi eGovernment, karena dari segi ketersediaan anggaran tersebut melihat kemampuan keuangan daerah, sedangkan untuk pertanggungjawabannya membutuhkan keberanian dari pimpinan instansi pemerintah terkait berhasil atau tidaknya implementasi eGovernment.

Di Pemerintah Daerah Kabupaten Nganjuk, ada beberapa Organisasi Pemerintah Daerah yang sudah menerapkan e-Government. Salah satunya adalah Badan Perencanaan Pembangunan Daerah Kabupaten Nganjuk (BAPPEDA). Implementasi e-Government di Badan Perencanaan Pembangunan Daerah Kabupaten Nganjuk melalui sistem aplikasi ePlanning membutuhkan dana yang besar dan dalam pengembangannya melalui beberapa tahap dengan jangka waktu yang lama.

3. Keterbatasan Sumber Daya Aparatur Sipil Negara pendukung implementasi e-Government.

Berdasarkan hasil wawancara dari narasumber diperoleh keterangan bahwa masih banyak Aparatur Sipil Negara di lingkungan pemerintah daerah Kabupaten Nganjuk yang belum memahami apa itu konsep e-Government. Fakta yang dapat dilihat dari kurangnya pemahaman Aparatur Sipil Negara tersebut terhadap konsep e-Government adalah sebagai berikut :

a. Kurangnya minat untuk belajar secara mandiri.

b. Masih menggunakan cara-cara lama dalam pelaksanaan tugas pokok dan fungsinya.

c. Penerapan e-Government yang masih jauh dari konsep e-Governent.

Kurangnya pemahaman konsep e-Government mempunyai dampak yang signifikan terhadap proses penyampaian data dan informasi sehingga menimbulkan kesan birokrasi pemerintahan yang berbelit-belit dengan proses pelayanan yang lama.

\section{E. KESIMPULAN}

Berdasarkan uraian dari hasil penelitian yang telah disampaikan mengenai implementasi kebijakan e-Government pada BAPPEDA Kabupaten Nganjuk, maka dapat ditarik kesimpulan sebagai berikut :

1. Implementasi kebijakan e-Government pada BAPPEDA Kabupaten Nganjuk dapat dikatakan sudah sesuai dengan konsep eGovernment, karena dalam menunjang pelaksanaan tugas pokok dan fungsinya di bidang perencanaan pembangunan daerah sudah memanfaatkan teknologi informasi dan komunikasi, yaitu dengan diterapkannya sistem aplikasi e-Planning. Implementasi kebijakan eGovernment pada BAPPEDA Kabupaten Nganjuk dapat dilihat dari beberapa hal yang mendasar, yaitu:

a. Proses penyusunan perencanaan sudah dilakukan secara online, yaitu dengan menggunakan Sistem Informasi Perencanaan Pembangunan Daerah atau e-Planning. Penyusunan perencanaan dalam sistem aplikasi ePlanning tersebut meliputi penyusunan RPJMD, Renstra, RKPD, Renja, dan penerbitan KUAPPAS. Sedangkan mekanisme penyusunannya melalui beberapa tahapan, yaitu : 1) input data yang meliputi informasi program, kegiatan dan anggaran yang dimiliki oleh Organisasi Perangkat Daerah; 2) proses yang memuat informasi mengenai waktu pelaksanaan program dan kegiatan Organisasi Perangkat Daerah; 3) output yang memuat informasi mengenai hasil yang diperoleh dari pelaksanaan program dan kegiatan Organisasi Perangkat Daerah; 4) outcome yang memberikan informasi mengenai dampak yang akan diperoleh apabila program dan kegiatan yang direncanakan telah terlaksana. 
b. Publikasi penggunaan e-Planning oleh BAPPEDA Kabupaten Nganjuk kepada seluruh OPD di Kabupaten Nganjuk disampaikan melalui sosialisasi, pelatihan, surat dinas, dan penyampaian secara langsung pada waktu Musrenbang.

2. Dalam implementasi kebijakan eGovernment pada Badan Perencanaan Pembangunan Daerah Kabupaten Nganjuk terdapat 3 (tiga) faktor penghambat, yaitu:

a. Kebijakan Pemerintah Daerah yang mendukung implementasi kebijakan eGovernment pada BAPPEDA Kabupaten Nganjuk untuk saat ini belum ada.

b. Sumber daya finansial atau ketersediaan dana dan anggaran dalam implementasi kebijakan e-Government pada BAPPEDA Kabupaten Nganjuk sepenuhnya berasal dari Anggaran Pendapatan dan Belanja Daerah (APBD). Untuk implementasi kebijakan eGovernment tersebut membutuhkan dana yang cukup besar, sehingga dalam pembiayaannya dilakukan secara bertahap sesuai dengan kemampuan keuangan daerah.

c. Ketersediaan sumber daya aparatur dalam implementasi e-Government pada BAPPEDA Kabupaten Nganjuk sudah sesuai dengan kebutuhan, sedangkan yang menjadi kendala adalah sumber daya aparatur pada tingkat kecamatan. Pada tingkat kecamatan masih memiliki sumber daya aparatur yang terbatas baik dari segi jumlah maupun kualitasnya. Kebiasaan bekerja dengan menggunakan caracara lama juga menjadi kendala dalam implementasi e-Government pada tingkat kecamatan.

Berdasarkan hasil penelitian yang telah diuraikan, maka peneliti dapat memberikan rekomendasi atau saran guna menunjang implementasi e-Government baik untuk BAPPEDA Kabupaten Nganjuk maupun Organisasi Perangkat Daerah yang lain.

1. Adanya kebijakan pemerintah daerah berupa peraturan daerah maupun peraturan bupati yang mendukung implementasi eGovernment di Kabupaten Nganjuk. Harapannya dengan adanya kebijakan pemerintah daerah tersebut dapat menjadi landasan hukum dan solusi permasalah terkait implementasi eGovernment di Organisasi Perangkat Daerah Kabupaten Nganjuk.

2. Adanya pengembangan sistem aplikasi ePlanning Badan Perencanaan Pembangunan Daerah Kabupaten Nganjuk dengan tambahan modul legalitas Kepala Organisasi Perangkat Daerah. Harapannya dengan adanya modul legalitas secara online akan mempermudah proses verifikasi di Badan Perencanaan
Pembangunan Daerah sendiri tentunya dari segi waktu.

\section{E. REFERENSI}

Arikunto, Suharsimi, 2006, Prosedur Penelitian : Suatu Pendekatan Praktek, Jakarta : Asdi Mahasatya.

Bungin, Burhan, 2001, Metodologi Penelitian Sosial : Format-format Kuantitatif dan Kualitatif, Surabaya : Airlangga University Press.

C. Edward III, George, 2001, Implementing Public Policy, Washinton : Congressional Quarterly Press.

Dessler, G, 1997, Hukum Resource Management, Jakarta : Prenhallindo.

Dwiyanto, Agus, et.al., 2002, Reformasi Birokrasi Publik Di Indonesia, Cetakan Pertama, Yogyakarta : Pusat Studi Kependudukan dan Kebijakan Universitas Gadjah Mada.

Hamidah, Nur Rahmawati, 2015, Implementasi eGovernment dalam Pelayanan (Studi Kasus Penerapan Program SIAKAD di STAIN Ponorogo). Tesis tidak diterbitkan. Surakarta : PPs Universitas Sebelas Maret Surakarta

Indrajit, Richardus Eko. 2006. E-Government in Action. Yogyakarta: Andi Yogyakarta.

Instruksi Presiden Republik Indonesia Nomor 3 tahun 2003 Tentang Kebijakan dan Strategi Nasional Pengembangan eGovernment.

Islamy, M. Irfan, 2001, Prinsip-prinsip Perumusan kebijakan Negara, Jakarta : Bumi Aksara.

Moleong, Lexy J. 2016. Metode Penelitian Kualitatif, edisi revisi. Bandung : PT. Remaja Rosdakarya.

Nia Karniawati, Romi Rahmadani, 2011, “Analisis Kebijakan Penerapan e-Government Melalui Sistem Informasi Manajemen Kepegawaian (SIMPEG) : Suatu Studi Pada Biro Kepegawaian Sekretariat Daerah Provinsi Jawa Barat". Jurnal bidang Humaniora Unikom. Vol.7, No.2.

$\begin{array}{rcr}\text { Rencana Strategis } & \text { Badan } & \text { Perencanaan } \\ \text { Pembangunan } & \text { Daerah } & \text { Kabupaten } \\ \text { Nganjuk Tahun } 2014-2018 . & \end{array}$

Santy Nurina Aprilia1, Andy Fefta Wijaya, dan Suryadi, 2014, “Efektivitas Website Sebagai Media e-Government dalam Meningkatkan Pelayanan Elektronik Pemerintah Daerah : Studi Pada Website Pemerintah Daerah Kabupaten Jombang". Jurnal Sosial dan Humaniora Unibraw. Vol.17, No.3. 


\section{MEDIA5OSIAN}

Jurnal Ilmu Sosial dan Ilmu Administrasi Negara Vol. 2 No. 1

Sugiyono, 2015, Metode Penelitian Kuantitatif, Kualitatif dan R \& D, Bandung: CV Alfabeta.

Subarsono AG, 2005, Analisis Kebijakan Publik Konsep, Teori dan Aplikasi, Yogyakarta : Pustaka Pelajar.

Wahab, Solichin Abdul, 2008, Analisis Kebijakan dari Formulasi ke Implementasi Kebijahanaan Negara, Edisi Kedua, Jakarta : Bumi Aksara.

William, Dunn, 1998, Pengantar Analisis Kebijakan Publik. Yogyakarta : Gadjah Mada University Press.

Winarno Budi, 2005, Kebijakan Publik teori dan proses, cetakan kedua, Yogyakarta : Media Pressindo. 